\title{
Macroeconomic Digital Book Development: How are the Feasibility of Experts and Student Responses?
}

\author{
Fachruddiansyah Muslim ${ }^{*}$, Refnida ${ }^{2}$, Diki Chen $^{3}$, Ricky Purnama Wirayuda \\ 1,2,3,4 Faculty of Teaching and Education, Jambi University, Jambi, Indonesia \\ e-mail: oktavianiwidya585@gmail.com
}

\section{A R T I C L E I N F O}

Article history:

Received June 10, 2021

Revised June 11, 2021

Accepted July 20, 2021

Available online August 25, 2021

Kata Kunci:

Buku Digital, Makroekonomi,

Respon mahasiswa

Keywords:

Digital Book,

Macroeconomics, Students

Response

DOI:

http://dx.doi.org/10.23887/jet.v $5 i 3.38280$

\begin{abstract}
A B S T R A K
Masih banyak guru yang belum memanfaatkan teknologi sebagai sumber belajar bagi siswa. Hal ini menyebabkan bahan ajar yang dimiliki siswa kurang menarik. Penelitian ini bertujuan untuk melihat kelayakan produk yang dikembangkan yaitu buku digital pada materi makroekonomi. Kelayakan buku digital yang dibuat terbagi menjadi dua yaittu kelayakan dari para ahli dan kelayakan dari sampel (mahasiswa). Penelitian ini berjenis $R \& D$ dengan model pengembangan yang dipilih yaitu model pengebangan ADDIE. Teknik pengambilan sampel yang digunakan yaitu simpel random sampling dengan sampel yang digunakan sebanyak 36 mahasiswa aktif prodi pendidikan ekonomi. Instrumen pengumpulan data yang digunakan ada 3 meliputi instrumen validasi ahli media dan materi yang memiliki 10 pernyataan dan instrumen respon mahasiswa yang berjumlah 28 pernyataan. Analisis data yang digunakan berupa statistik deskriptif. Hasil validasi materi untuk kedua validator didapatkan sebesar 42 (sangat baik) dan 37 (baik), kemudian untuk ahli media didapatkan skor sebesar 38 (baik) dan 39 (baik), sedangkan untuk respon mahasiswa pada aspek materi didapatkan skor sebesar 29.25 (direkomendasikan), aspek media sebesar 52,5 (sangat direkomendasikan), aspek output sebesar 9.75 (direkomendasikan), dan untuk semua aspek sebesar 91.5 (sangat direkomendasikan). Berdasarkan hasil yang telah didapatkan dari validasi maupun uji coba kelompok kecilnya menunjukkan bahwa buku diital pada materi makroekonomi sudah layak digunakan sebagai sumber belajar pelengkap pada perkuliahan materi makroekonomi.
\end{abstract}

\section{A B S T R A C T}

There are still many teachers who have not used technology as a learning resource for students. This causes the teaching materials that students have less attractive. This study aims to see the product's feasibility, namely a digital book on macroeconomic material. The feasibility of the digital-book is divided into two, namely, the feasibility of the experts and the feasibility of the sample (students). This research is an R\&D type with the selected development model, namely the ADDIE development model. The sampling technique used is simple random sampling with a sample of 36 active students of an economic education study program. There are 3 data collection instruments used, including media and material expert validation instruments with ten statements and student response instruments totalling 28 statements. Analysis of the data used in the form of descriptive statistics. The results of material validation for both validators were 42 (very good) and 37 (good), then for media experts, scores were 38 (good) and 39 (good), while for student responses to the material aspect, a score of 29.25 (recommended) was obtained. , the media aspect is 52.5 (highly recommended), the output aspect is 9.75 (recommended), and for all aspects, 91.5 (highly recommended). Based on the results obtained from the validation and small group trials, digital books on macroeconomic material are appropriate to be used as complementary learning resources in macroeconomics lectures.

This is an open access article under the $\underline{C C B Y-S A}$ license.

Copyright (C) 2021 by Author. Published by Universitas Pendidikan Ganesha.

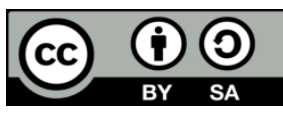

\section{INTRODUCTION}

Universities themselves play an important role in producing skilled human resources (Blesia et al., 2021; Sahu, 2020). In recent decades, efforts to increase the capacity of higher education institutions have become a challenge to meet the needs of Indonesia's skilled young generation (Cahyadi, 2020). In 1980, Indonesia first initiated the expansion of higher education on the basis of the demand for skilled graduates (Brewis, 2019; Gunawan et al., 2019). Currently, this is still being done, especially with the development of technology that is rapidly making education not limited by time and place. With this technology, of course, it 
helps educators, in this case lecturers, to create interesting learning in terms of the environment or media used (Baya'a et al., 2019; Chang et al., 2020; Sadaf \& Johnson, 2017).

There is no doubt that technology has become an important thing in education in today's digital era (Hashim, 2018; MacLachlan et al., 2018; Sarker et al., 2019). Until now technology has played a role as a supporter in improving learning outcomes and teaching and learning processes, this includes collecting material on the internet or using applications as a method of presenting material (Haji et al., 2017; Martirosyan et al., 2019; Nordlöf et al., 2019). In addition to this, technology can also be used as a teacher complement in improving practice in education (Fu \& Hwang, 2018; Muhtadi et al., 2018; Tondeur et al., 2019). The problem that occurs today is that many teachers have not used technology as a learning resource for students (Sidiq \& Najuah, 2020; Winatha et al., 2018). This causes the teaching materials owned by students to be less attractive (Fonda \& Sumargiyani, 2018; Raharjo et al., 2017). In using technology in the field of education, sufficient knowledge and experience is needed so that there is no misrepresentation of information or material in class. One example of presenting flexible and interactive digital-based materials can be found in the application of epub-based digital books.

Digital books today have become a trend that is in great demand because they have some very profitable potential (Stover et al., 2016; Prasetya et al., 2018; Bus et al., 2020). Digital books are digital forms of printed books that can be displayed on computers or other electronic devices (Sezgin \& Ulus, 2017; Marselina et al., 2019; Korat et al., 2021). Digital books in their use become a real solution in solving the problems and drawbacks of print-based books. Digital books will not be damaged or run out because they are basically intangible like printed books (Ozturk \& Hill, 2020; Hidayati \& Elmunsyah, 2021). With these various conveniences, of course, digital books are superior in terms of ease of access and durability compared to printed books. That way, the researcher intends to develop an epub-based digital book on macroeconomics lecture material.

Macroeconomics or often called macroeconomics is one part of the economic field that discusses all economic problems (Jusman \& Puspitasari, 2019; Giffarina, 2021). Fields of macroeconomic studies include inflation, interest rates, exchange rates, imports, exports, world oil prices, and others (Mota-Hernandez et al., 2014; Salim, 2016; Candy \& Winardy, 2018; Kennedy \& Hayrani, 2018). Macroeconomic studies are explained in detail based on the economic problems of a country, therefore the topics discussed tend to be more numerous and complex. Macroeconomics learning tends to be memorizing so that in this case it requires an interactive media that can explain the complexities studied in macroeconomics. Based on this, the best solution is to develop an interactive multimedia-based digital book that can be accessed digitally.

Digital books are durable and flexible both in terms of time and use (Sargeant, 2015; Mawarni \& Muhtadi, 2017; Kholiq, 2020). Digital books in macroeconomic learning are very appropriate innovations in facilitating student lectures. In addition, in macroeconomic learning there are also many important terms that students must remember, therefore by using digital books it is easy to find these complicated terms (Yildiz \& Gunsoy, 2017; Kuorikoski \& Lehtinen, 2018). Students no longer need to go back and forth looking for these terms because this can be handled by looking in the search column in digital books. In addition to this, from the perspective of the teacher or lecturer, this is a good innovation in helping lecturers to find more varied learning resources.

This research is a refinement of previous research. Previous research from several experts has integrated economic learning with electronic modules (Reneman et al., 2021). More specifically, research from (Arico et al., 2018; Nyatanga \& Mukorera, 2019) macroeconomic material can be used as material for developing a module. In terms of material, there is no research that uses macroeconomic material as material for developing digital books. Previous research from several experts (Dewi et al., 2018; Liao et al., 2018; Wusqo et al., 2021) chose non-economic materials in developing a digital book. Then in terms of research variables, several experts examined the effectiveness of using digital books with printed books (Suyatna et al., 2018; Siwiendrayanti et al., 2019; Suryani et al., 2021). Previous research shows that there is no research on the development of digital books on macroeconomic material, previous research is only limited to the development of macroeconomic modules. The author's research is only limited to digital books and does not use other variables such as printed books or modules. Based on the urgency and previous research objectives of this research are as follows: (1) describe the feasibility of digital book materials for macroeconomic materials developed, (2) describe the feasibility of digital book media for macroeconomic materials developed, and (3) describe student responses regarding the products developed.

\section{METHOD}

The type of research conducted by the author is $R \& D$. R\&D research is one of the research methods used to produce a product whose effectiveness is tested (Hamidah et al., 2014; Purwanto \& Rizki, 2015). The development model used is the ADDIE development model which consists of analysis, design, development, 
implementation, and evaluation. The ADDIE model is preferred because it is considered more complete and rational than other development models (Muruganantham, 2015; Suryaningsih, 2017).

Data was taken using simple random sampling with data analysis techniques in the form of descriptive statistics, according to Lone \& Tailor (2017) simple random sampling is commonly used by researchers to predict the variance of a sample population. The samples taken in this study were 36 active students whose allocation was used in small group trials and student responses to e-pub-based digital books. As for the validation using a questionnaire as a data collection instrument. As for the material expert validation instrument grid, it can be seen in table 1.

Table 1. Grid of Material Expert Assessment Instruments

\begin{tabular}{|c|c|c|}
\hline No. & Rated aspect & Statement Number \\
\hline 1 & Preliminary & 1,2 \\
\hline 2 & Contents & 2,4 \\
\hline 3 & Curriculum & 4,5 \\
\hline 4 & Economic Concept & 6,7 \\
\hline 5 & Summary & 9 \\
\hline 6 & Assignments/Tests & 10 \\
\hline
\end{tabular}

Then for the validation of media experts, several aspects related to the use of contents in digital books were used. The aspects assessed can be seen in table 2 relating to the media expert validation instrument grid.

Table 2 . Media Expert Assessment Instrument Grid

\begin{tabular}{clll}
\hline No. & & Rated aspect & Statement Number \\
\hline 1 & Component & 1,2 & \\
2 & Content & $3,4,9$ & \\
3 & Interface & $5,6,10$ & \\
4 & Interactivity & 7,8 & \\
\hline
\end{tabular}

From tables 1 and 2 it is known that there are 10 statements that are assessed using a Likert scale of 1 to 5 with details, 1 (very bad), 2 (not good), 3 (enough), 4 (good), and 5 (very good). not good). Because media and material experts have the same number of aspects and Likert scales, the scoring categories are also the same as each other. The scoring categories can be seen in table 3 below.

Table 3 . Scoring Category Material Expert and Media Expert Assessment

\begin{tabular}{ccc}
\hline Score Interval & Category & Information \\
\hline $40.01-50.00$ & Very Good & No Need Revision \\
$30.01-40.00$ & good & No Need Revison \\
$20.01-30.00$ & Enough & Need a Little Revision \\
$15.01-20: 00$ & Bad & Need Revision \\
$10.00-15.00$ & Very Bad & Need Revison \\
\hline
\end{tabular}

Then to assess the benefits of the product, an assessment of student responses was carried out which was divided into several indicators. The student response questionnaire has 28 statements with a Likert scale of 1 to 4 with details of 1 (strongly disagree), 2 (disagree), 3 (agree), and 4 (strongly agree). To determine whether digital books are suitable for use based on student opinions, a scoring category is needed which can be seen in table 4.

Table 4. Category Student Response Material Aspects in Digital Books

\begin{tabular}{cc}
\hline Score Interval & Category \\
\hline $29.26-36.00$ & Very Worth it \\
$22.6-29.25$ & Worth it \\
$15.76-22.5$ & Not worth it \\
$9.00-15.75$ & Very Not Worth it \\
\hline
\end{tabular}

After seeing the response to the material aspect, the researcher then looked at the categories in the media aspect. The categories of student responses to the media aspect can be seen in the following table 5 . 
Table 5 . Category Student Response M edia Aspects in Digital Books

\begin{tabular}{cc}
\hline Score Interval & Category \\
\hline $52.1-64.0$ & Very Worth it \\
$40.1-52.0$ & Worth it \\
$28.1-40.0$ & Not worth it \\
$16.0-28.0$ & Very Not Worth it \\
\hline
\end{tabular}

After seeing the response to the media aspect, the next researcher also looked at the categories in the aspect of output or output. The categories of student responses on the output aspect can be seen in the following table 6.

Table 6. Cat egory Student Response Output Aspects in Digital Books

\begin{tabular}{cc}
\hline Score Interval & Category \\
\hline $9.76-12.00$ & Very Worth it \\
$7.51-9.75$ & Worth it \\
$5.26-7.50$ & Not worth it \\
$3.00-5.25$ & Very Not Worth it \\
\hline
\end{tabular}

After seeing the response to the external aspect, the next researcher also looked at the category in the overall aspect. The categories of student responses in all aspects can be seen in the following table 7 .

Table 7. Cat egory Student Response All Aspects in Digital Books

\begin{tabular}{cc}
\hline Score Interval & Category \\
\hline $91.1-112.0$ & Very Worth it \\
$70.1-91.0$ & Worth it \\
$49.1-70.0$ & Not worth it \\
$28.0-49.0$ & Very Not Worth it \\
\hline
\end{tabular}

The procedure for conducting the research begins with analyzing (Analysis) problems through literature studies and then conducting field studies by observing the potential that has been obtained on campus in supporting the learning process starting from product development that will be produced according to the needs of students themselves, student knowledge in using electronic devices such as computers, and tentative documents of learning outcomes. macroeconomics that has been done by students. For the specification of activities, the orientation of the activities is determined for the initial determination of the learning objectives themselves; analyze student categorization; and analyze the needs and application of basic competencies acquired during learning. Then for the design stage there are 5 activities carried out, namely formulating the success of the indicators used, choosing the research procedures carried out, determining learning methods, determining topics or materials and making flow charts based on storyboards. Then for the development stage, which is the realization of the design stage that has been designed, at this stage an instrument for measuring product performance is also made. The next stage is the implementation stage where there are several activities carried out, namely distributing or giving digital books to students. After this is completed, the last stage is to carry out an evaluation which consists of several activities, namely conducting comprehensive continuous monitoring and evaluation in the form of published studies on activities, end of activities, and non-formal activities, conducting formal evaluations consisting of alpha test involving validators related to materials and media that have been analyzed, as well as conducting beta test activities consisting of several educators and involving approximately 10 students with various competency backgrounds (high, medium, and low). At the end of the activity, a summative evaluation was carried out in the form of a feasibility test on the final product that had been perfected, in addition, a comprehensive evaluation was carried out regarding students' cognitive and interpersonal abilities. which has been previously tested from the use of the product.

\section{RESULT AND DISCUSSION}

Result

Validation was carried out twice, namely on the material and media used. The validation results from the two experts. Based on the results of data analysis, the assessments given by learning content experts were 42 and 32 , so the developed media received very good qualifications. The assessment results of the learning media 
experts scored 38 and 39 so that the developed media received good qualifications. After the product in the form of a digital book has been validated, the researcher then reviews the benefits of digital books for students. The material aspect as many as 22 students $(61.11 \%)$ highly recommend it while 14 students recommend it. Then for the media aspect, 18 people highly recommend it and 18 people recommend it. Then for the output aspect, 23 students highly recommend it while the remaining 13 students recommend digital books. Then for all aspects, it can be seen that 24 students $(66.67 \%)$ highly recommend it and the remaining 12 students recommend it.

The development of a product related to technology in education is becoming an important thing today (Chien, 2017; Snape \& Zealand, 2017). Before being tested on samples or students, a product in this case is a digital book on macroeconomic material, it is important to carry out a validation which indicates that the product is feasible to be tested (Komatsu et al., 2017; Price et al., 2017; Silva et al., 2019). The validation used in developing digital books is to use media experts and material experts. The material expert shows the suitability assessment and selection of the materials used, while the media expert shows the design assessment from the digital book (Arista \& Kuswanto, 2018; Ismara et al., 2021). Based on table 9, it is found that the results are in the good and very good categories, referring to these results it can be concluded that digital books are worthy of trial by considering the suitability of the materials and media used are attractive, creative, and innovative.

After the product was suitable for use, the researcher then conducted a small group trial by taking student responses to digital books. The trial kelo m small group carried out to look at the feasibility of digital books based on the views of students (Outhwaite et al., 2019; Griffith et al., 2020). The results obtained show that the material aspect gets an average score of 29.25 (worth it), the media aspect gets 52.5 (very worth it), for the output aspect it gets a score of 9.75 (worth it), and for all aspects it gets a score of 91.5 (very worth it). it). The results of the small group trial show that digital books are worthy of being a source of student learning, this can be shown from the responses of students who mostly recommend digital books to become a learning resource in macroeconomics lectures. The results obtained indicate that students basically want interesting and flexible learning, but this is mostly not done often because it is constrained by monotonous and boring learning resources (Zaki et al., 2020; Zetriuslita et al., 2020). Most students expect a learning innovation to come from the method or source of learning such as the use of digital books.

Digital book is basically a flexible and portable media resource (Block \& Kühn, 2017; Fürstenberg \& Weßling, 2018; Schlimbach \& Asghari, 2020). Its flexible and portable nature makes many educators and teachers interested in developing and implementing it in the classroom (Faniband et al., 2020; Hassan Al-Ahdal, 2020). However, it is not easy. It takes not only material knowledge but also thorough technological knowledge. Many teachers stop in the middle of the road in developing digital books, especially on economics. Most of them think that they do not have time to work because the teaching schedule is quite busy coupled with the nature of books in general which are dense in the material. The researcher considers that this should not be allowed to continue if the teacher or educator does not have enough time. The researcher thinks to help the teacher by making a digital book, especially on macroeconomic material. The macroeconomic material itself was chosen because of its complex and varied nature so that it required the combination of each part of the material covering various sources.

This research brings fresh air to teachers in implementing technology in classroom learning. The implications of this research can be viewed from various aspects, one of which is the subject of education, one of which includes students, teachers or lecturers, and the institutions themselves. For students, this book can be used as a guide or a complement to macroeconomic learning resources which tend to be complex and mostly varied. Developing books contain actual materials and also very interesting in terms of graphics. With this interest, it certainly makes learning more comfortable and innovative again. In addition, with a simple but complex explanation, it makes it easier for students to absorb information related to economic problems that tend to be varied and different in each region and country. On the other hand, long-term use can improve the pedagogical abilities of prospective economics teachers, most of which require strong analytical skills on economic problems (Hogan \& Devi, 2019; Shastina et al., 2020; Han \& Zhang, 2021). Based on this, it can be concluded that this digital book can be a real solution in overcoming students' problems in understanding macroeconomic material. Then for teachers such as lecturers or teachers, this is a good and innovative complementary source of learning. Teachers do not need to bother interpreting sentences or words, because this digital book is explained in a simple way but does not reduce the complexity of the material. In addition, important terms can be searched easily using digital books compared to printed books which are quite troublesome in finding an important term. For an educational institution, this is very important in achieving the vision and mission that they have previously made (Pöntinen \& Räty-Záborszky, 2020; Saddhono et al., 2019; Yikici et al., 2019). Most of an educational institution has a vision of producing a qualified graduate both in terms of knowledge and attitude. With this digital book, it can directly improve the quality of students so that it can make agencies in this case study programs to increase accreditation or maintain their previous accreditation. On the other hand, the use of digital books that reflect the use of technology in education shows that an agency 
or study program is not out of date with other agencies, this also results in healthy competition in innovation and creativity, especially in macroeconomic economics learning material (Smith et al., 2018; Weiss et al., 2018).

This research is a refinement of previous research. Research from Saputri et al., (2021) focuses on the development of digital books on $\mathrm{m}$ ateri overall economy and not discuss the specifics of the material. Meanwhile, research from (Rasmawan, 2020; Supriyadi et al., 2020) takes a specific theme again, but the study material is not economic learning, especially macroeconomics. Then several previous studies from several experts showed that the effectiveness of digital books can be compared with ordinary printed books (Uygarer \& Uzunboylu, 2017; Suyatna et al., 2018; Abed, 2019). Then in terms of the sample used, the study was limited to using only one class of 36 samples, this is different from previous research from (Shehu \& Jere, 2016; Ibrahim \& Alqahtani, 2018) which took more samples than the author's research. Research is not always perfect. In the author's research, only used a small sample of 36 students. In addition, this study only focuses on digital books and does not compare them with other variables as did some experts (Küpper \& Alonso, 2019) using two variables, namely printed books and digital books. The data analysis used is also limited to descriptive statistics and does not use assumption testing and hypothesis testing. Based on this, the researcher suggests for further research to add several more classes so that hypothesis testing can be carried out. In addition, using two variables in the form of printed books and digital books can make research even more varied.

\section{CONCLUSION}

Student responses, both in terms of material, media, output, and overall aspects showed positive results where most of them recommended this digital book. Based on this, it can be concluded that this digital book is good and feasible to use both in terms of experts and from the user side, namely the students themselves.

\section{REFERENCES}

Abed, E. K. (2019). Electronic learning and its benefits in education. Eurasia Journal of Mathematics, Science and Technology Education, 15(3). https://doi.org/10.29333/ejmste/102668.

Arico, F., Gillespie, H., Lancaster, S., Ward, N., \& Ylonen, A. (2018). Lessons in learning gain: Insights from a pilot project. Higher Education Pedagogies, 3(1), 249-265. https://doi.org/10.1080/23752696.2018.1454845.

Arista, F. S., \& Kuswanto, H. (2018). Virtual physics laboratory application based on the android smartphone to improve learning independence and conceptual understanding. International Journal of Instruction, 11(1), 1-16. https://doi.org/10.12973/iji.2018.1111a.

Baya'a, N., Daher, W., \& Anabousy, A. (2019). The development of in-service mathematics teachers' integration of ICT in a community of practice: Teaching-in-context theory. International Journal of Emerging Technologies in Learning, 14(1), 125-139. https://doi.org/10.3991/ijet.v14i01.9134.

Blesia, J. U., Iek, M., Ratang, W., \& Hutajulu, H. (2021). Developing an Entrepreneurship Model to Increase Students' Entrepreneurial Skills: an Action Research Project in a Higher Education Institution in Indonesia. Systemic Practice and Action Research, 34(1), 53-70. https://doi.org/10.1007/s11213-01909506-8.

Block, B., \& Kühn, R. (2017). E-Book-Metadaten Pool und E-Book-Management Tool - ein Kooperationsprojekt von BSZ und VZG. Bibliotheksdienst, 51(8), 664-674. https://doi.org/10.1515/bd2017-0072.

Brewis, E. (2019). Fair access to higher education and discourses of development: a policy analysis from Indonesia. Compare: A Journal of Comparative and International Education, 49(3), 453-470. https://doi.org/10.1080/03057925.2018.1425132.

Bus, A. G., Neuman, S. B., \& Roskos, K. (2020). Screens, Apps, and Digital Books for Young Children: The $\begin{array}{llll}\text { Promise of } \quad \text { Multimedia. } & \text { OpRA }, & 6(1), \quad 285842090149 .\end{array}$ https://doi.org/10.1177/2332858420901494.

Cahyadi, A. (2020). Covid-19 Outbreak and New Normal Teaching in Higher Education: Empirical Resolve from Islamic Universities in Indonesia. Dinamika Ilmu, 20(2), 255-266. https://doi.org/10.21093/di.v20i2.2545.

Candy, C., \& Winardy, A. (2018). Pengaruh Faktor Ekonomi Makro Terhadap Stock Return Pada Indeks Saham LQ45. Jesya (Jurnal Ekonomi \& Ekonomi Syariah), 2(1), 65-79. https://doi.org/10.36778/jesya.v2i1.35.

Chang, T. Y., Hong, G., Paganelli, C., Phantumvanit, P., Chang, W. J., Shieh, Y. S., \& Hsu, M. L. (2020). Innovation of dental education during COVID-19 pandemic. Journal of Dental Sciences, 155. https://doi.org/10.1016/j.jds.2020.07.011.

Chien, Y. H. (2017). Developing a pre-engineering curriculum for 3D printing skills for high school technology 
education. Eurasia Journal of Mathematics, Science and Technology Education, 13(7), 2941-2958. https://doi.org/10.12973/eurasia.2017.00729a.

Dewi, N. R., Kannapiran, S., \& Wibowo, S. W. A. (2018). Development of digital storytelling-based science teaching materials to improve students' metacognitive ability. Jurnal Pendidikan IPA Indonesia, 7(1), 16-24. https://doi.org/10.15294/jpii.v7i1.12718.

Faniband, Y. P., Ishak, I., Sidi, F., \& Jabar, M. A. (2020). A Cloud-Based Distributed Platform for Secured EPUB EBOOK Contents. International Journal of Emerging Trends in Engineering Research, 8(10), 6630-6637. https://doi.org/10.30534/ijeter/2020/018102020.

Fonda, A., \& Sumargiyani, S. (2018). The Developing Math Electronic Module With Scientific Approach Using Kvisoft Flipbook Maker Pro For Xi Grade Of Senior High School Students. Infinity Journal, 7(2), 109122. https://doi.org/10.22460/infinity.v7i2.p109-122.

Fu, Q. K., \& Hwang, G. J. (2018). Trends in mobile technology-supported collaborative learning: A systematic review of journal publications from 2007 to 2016. Computers and Education, 119(July 2017), 129-143. https://doi.org/10.1016/j.compedu.2018.01.004.

Fürstenberg, T., \& Weßling, J. (2018). Flexibel, evidenzbasiert, zielorientiert - Zur Gestaltung einer modernen ambulanten Vergütung. Gesundheits- Und Sozialpolitik, 72(4-5), 38-43. https://doi.org/10.5771/16115821-2018-4-5-38.

Giffarina, R. (2021). Determinan Indeks Harga Saham Gabungan: Perspektif Makroekonomi. Journal of Public Auditing and Financial Management, 1(1), 1-12.

Griffith, K. R., Price, J. N., \& Penrod, B. (2020). The Effects of a Self-Instruction Package and Group Training on Trial-Based Functional Analysis Administration. Behavior Analysis in Practice, 13(1), 63-80. https://doi.org/10.1007/s40617-019-00388-9.

Gunawan, F., Mayasari, R., Muna, W., \& Masruddin, M. (2019). Lecturer's Language Style and Students' Academic Self Efficacy in Higher Education of Indonesia. Arab World English Journal, 10(2), 77-87. https://doi.org/10.24093/awej/vol10no2.7.

Haji, S. A., Moluayonge, G. E., \& Park, I. (2017). Teachers' use of information and communications technology in education: Cameroon secondary schools perspectives. Turkish Online Journal of Educational Technology, 2017(November Special Issue IETC), 671-679.

Hamidah, A., Sari, E. N., \& Budianingsih, R. S. (2014). Persepsi Siswa Tentang Kegiatan Praktikum Biologi di Laboratorim SMA Negeri Se-Kota Jambi. Jurnal Sainmatika, 8(1), 49-59.

Han, H., \& Zhang, L. (2021). Critical Pedagogy in Hong Kong: Classroom Stories of Struggle and Hope. Journal of International Students, 11(1), 274-277. https://doi.org/10.32674/jis.v11i1.3258.

Hashim, H. (2018). Application of Technology in the Digital Era Education. International Journal of Research in Counseling and Education, 1(2), 1. https://doi.org/10.24036/002za0002.

Hassan Al-Ahdal, A. A. M. (2020). EBook interaction logs as a tool in predicting learner performance in reading. Asiatic, $14(1), 174-188$.

Hidayati, L., \& Elmunsyah, H. (2021). Students 'Learning Motivation in Oriental Food Processing Course during Online Learning Using Digital Smart Book Learning Media. 44(1), 34-39.

Hogan, R., \& Devi, M. (2019). A synchronous pedagogy to improve online student success. International Journal of Online Pedagogy and Course Design, 9(3), 61-77. https://doi.org/10.4018/IJOPCD.2019070105.

Ibrahim, H., \& Alqahtani, A. S. H. (2018). The impact of adopting Web 2.0-based E-Book on student learning skills. Eurasia Journal of Mathematics, Science and Technology Education, 14(6), 2509-2522. https://doi.org/10.29333/ejmste/90085.

Islam Sarker, M. N., Wu, M., Cao, Q., Alam, G. M. M., \& Li, D. (2019). Leveraging Digital Technology for Better Learning and Education: A Systematic Literature Review. International Journal of Information and Education Technology, 9(7), 453-461. https://doi.org/10.18178/ijiet.2019.9.7.1246.

Ismara, K. I., Suharjono, A., \& Supriadi, D. (2021). Ubiquitous learning in occupational health and safety for vocational education. International Journal of Evaluation and Research in Education, 10(1), 285-292. https://doi.org/10.11591/IJERE.V10I1.20823.

Jusman, J., \& Puspitasari, S. . (2019). Pengaruh Kondisi Fundamental dan Inflasi Terhadap Bunga Saham pada Perusahaan Sub Sektor Perkebunan Tahun 2016-2018. Jurnal Ilmiah Ekonomi Bisnis (S4), 6(1), 84-98.

Kennedy, P. S. J., \& Hayrani, R. (2018). Pengaruh Faktor-faktor Ekonomi Makro: Inflasi, Harga Minyak, dan Harga Bahan Bangunan Terhadap Harga Saham Perusahaan Properti di BEI. Jurnal Mitra Manajemen, $2(1), 1-12$.

Kholiq, A. (2020). Development of B D F-AR 2 (Physics Digital Book Based Augmented Reality) to train students' scientific literacy on Global Warming Material. Berkala Ilmiah Pendidikan Fisika, 8(1), 50. https://doi.org/10.20527/bipf.v8i1.7881.

Komatsu, K., Jones, K., Ikeda, T., \& Narazaki, A. (2017). Proof validation and modification in secondary school 
geometry. Journal of Mathematical Behavior, 47, 1-15. https://doi.org/10.1016/j.jmathb.2017.05.002.

Korat, O., Tourgeman, M., \& Segal-Drori, O. (2021). E-book reading in kindergarten and story comprehension support. Reading and Writing, 0123456789. https://doi.org/10.1007/s11145-021-10175-0.

Kuorikoski, J., \& Lehtinen, A. (2018). Model selection in macroeconomics: DSGE and ad hocness. Journal of Economic Methodology, 25(3), 252-264. https://doi.org/10.1080/1350178X.2018.1488563.

Liao, S., Hong, J.-C., Wen, M.-H., Pan, Y.-C., \& Wu, Y.-. (2018). Applying Technology Acceptance Model (TAM) to explore Users' Behavioral Intention to Adopt a Performance Assessment System for E-book Production. EURASIA Journal of Mathematics, Science and Technology Education, 14(10). https://doi.org/10.29333/ejmste/93575.

Lone, H. A., \& Tailor, R. (2017). Estimation of population variance in simple random sampling. Journal of Statistics and Management Systems, 20(1), 17-38. https://doi.org/10.1080/09720510.2016.1187923.

MacLachlan, M., Banes, D., Bell, D., Borg, J., Donnelly, B., Fembek, M., Ghosh, R., Gowran, R. J., Hannay, E., Hiscock, D., Hoogerwerf, E. J., Howe, T., Kohler, F., Layton, N., Long, S., Mannan, H., Mji, G., Odera Ongolo, T., Perry, K., ... Hooks, H. (2018). Assistive technology policy: a position paper from the first global research, innovation, and education on assistive technology (GREAT) summit. Disability and Rehabilitation: Assistive Technology, 13(5), 454-466. https://doi.org/10.1080/17483107.2018.1468496.

Marselina, V., Muhtadi, A., Yogyakarta, U. N., \& No, J. C. (2019). Pengembangan Buku Digital Interaktif Matematika Pada Materi Geometri. Jurnal Inovasi Pendidikan Kimia, 6(2), 196-207.

Martirosyan, N. M., Saxon, D. P., \& Vick, N. T. (2019). Integrated Reading and Writing Course in Higher Education:Technology, Support Service, and Class Sizes as Reported By Faculty.

Mawarni, S., \& Muhtadi, A. (2017). Pengembangan Digital Book Interaktif Mata Kuliah Pengembangan Multimedia Pembelajaran Interaktif untuk Mahasiswa Teknologi Pendidikan. Jurnal Inovasi Teknologi Pendidikan, 4(1), 84-96.

Montero Küpper, S., \& Luna Alonso, A. (2019). The public image of book translators in the digital press. Studies in Systems, Decision and Control, 154, 313-328. https://doi.org/10.1007/978-3-319-918600_18.

Mota-Hernandez, C. I., Contreras-Troya, T. I., \& Alvarado-Corona, R. (2014). Holistic Complex-Systems Model to Solve Macroeconomics Issues ( HC-SMSMI ). Advances in Management \& Applied Economics, 4(4), 115-126.

Muhtadi, D., Wahyudin, Kartasasmita, B. G., \& Prahmana, R. C. I. (2018). The Integration of technology in teaching mathematics. Journal of Physics: Conference Series, 943(1), 1-9. https://doi.org/10.1088/1742-6596/943/1/012020.

Muruganantham, G. (2015). Developing Of E-Content Package By Using ADDIE Model. International Journal of Applied Research, 1(3), 52, p 52-54.

Nordlöf, C., Hallström, J., \& Höst, G. E. (2019). Self-efficacy or context dependency?: Exploring teachers' perceptions of and attitudes towards technology education. International Journal of Technology and Design Education, 29(1), 123-141. https://doi.org/10.1007/s10798-017-9431-2.

Nyatanga, P., \& Mukorera, S. (2019). Effects of lecture attendance, aptitude, individual heterogeneity and pedagogic intervention on student performance: A probability model approach. Innovations in Education and Teaching International, 205. https://doi.org/10.1080/14703297.2017.1371626.

Outhwaite, L. A., Faulder, M., Gulliford, A., \& Pitchford, N. J. (2019). Raising early achievement in math with interactive apps: A randomized control trial. Journal of Educational Psychology, 111(2), 284-298. https://doi.org/10.1037/edu0000286.

Ozturk, G., \& Hill, S. (2020). Mother-child interactions during shared reading with digital and print books. Early Child Development and Care, 190(9), 1425-1440. https://doi.org/10.1080/03004430.2018.1538977.

Pöntinen, S., \& Räty-Záborszky, S. (2020). Pedagogical aspects to support students' evolving digital competence at school. European Early Childhood Education Research Journal, 28(2), 182-196. https://doi.org/10.1080/1350293X.2020.1735736.

Prasetya, D. D., Wibawa, A. P., \& Hirashima, T. (2018). An interactive digital book for engineering education students. World Transactions on Engineering and Technology Education, 16(1), 54-59.

Price, C. J., Thompson, E. A., \& Cheng, S. C. (2017). Scale of Body Connection: A multi-sample construct validation study. PLoS ONE, 12(10), 1-13. https://doi.org/10.1371/journal.pone.0184757.

Purwanto, Y., \& Rizki, S. (2015). Pengembangan Bahan Ajar Berbasis Kontekstual Pada Materi Himpunan Berbantu Video Pembelajaran. AKSIOMA Journal of Mathematics Education, 4(1), 67-77. https://doi.org/10.24127/ajpm.v4i1.95.

Raharjo, M. W. C., Suryati, S., \& Khery, Y. (2017). Pengembangan E-Modul Interaktif Menggunakan Adobe Flash Pada Materi Ikatan Kimia Untuk Mendorong Literasi Sains Siswa. Hydrogen: Jurnal 
Kependidikan Kimia, 5(1), 8. https://doi.org/10.33394/hjkk.v5i1.102.

Rasmawan, R. (2020). Development of multi-representation based electronic book on inter molecular forces (IMFs) concept for prospective chemistry teachers. International Journal of Instruction, 13(4), 747762. https://doi.org/10.29333/iji.2020.13446a.

Reneman, M. F., Beemster, T. T., Welling, S. J., Mierau, J. O., \& Dijk, H. H. (2021). Vocational Rehabilitation for Patients with Chronic Musculoskeletal Pain With or Without a Work Module: An Economic Evaluation. Journal of Occupational Rehabilitation, 31(1), 84-91. https://doi.org/10.1007/s10926-02009921-y.

Sadaf, A., \& Johnson, B. L. (2017). Teachers' Beliefs About Integrating Digital Literacy Into Classroom Practice: An Investigation Based on the Theory of Planned Behavior. Journal of Digital Learning in Teacher Education, 33(4), 129-137. https://doi.org/10.1080/21532974.2017.1347534.

Saddhono, K., Sudarsana, I. K., \& Iskandar, A. (2019). Implementation of Indonesian Language the learning Based on Information and Communication Technology in Improving Senior High School Students' Achievement in Surakarta. Journal of Physics: Conference Series, 1254(1). https://doi.org/10.1088/1742-6596/1254/1/012059.

Sahu, P. (2020). Closure of Universities Due to Coronavirus Disease 2019 (COVID-19): Impact on Education and Mental Health of Students and Academic Staff. Cureus, 2019(4), 4-9. https://doi.org/10.7759/cureus.7541.

Salim, F. S. dan A. S. (2016). Kinerja Keuangan dan Kondisi Ekonomi Makro Terhadap Pengembalian Saham Perusahaan Property dan Real Estate yang Terdaftar di Bursa Efek Indonesia Periode Tahun 2011-2014. Jurnal Administrasi Kantor Bina Insani, 4(Vol. 4, No.1, Juni 2016), 47-67.

Saputri, K. Y., Santoso, S., \& Hindrayani, A. (2021). The Development of ARCS-Based Economic E-Book Media for Senior High School. Dinamika Pendidikan, 16(1), 83-93. https://doi.org/10.15294/dp.v16i1.29810.

Sargeant, B. (2015). What is an ebook? What is a Book App? And Why Should We Care? An Analysis of Contemporary Digital Picture Books. Children's Literature in Education, 46(4), 454-466. https://doi.org/10.1007/s10583-015-9243-5.

Schlimbach, R., \& Asghari, R. (2020). Das Digital Canvas: Ein Instrument zur Konzeption digitaler Geschäftsmodelle. HMD Praxis Der Wirtschaftsinformatik, 57(4), 866-878. https://doi.org/10.1365/s40702-020-00624-9.

Shastina, E. M., Jentgens, S., Shatunova, O. V., Borisov, A. M., \& Bozhkova, G. N. (2020). Role of literary pedagogy in modern education of preschool and primary school children. Space and Culture, 8(1), 234243. https://doi.org/10.20896/saci.v8i1.795.

Sidiq, R., \& Najuah. (2020). Pengembangan E-Modul Interaktif Berbasis Android Pada Mata Kuliah Strategi Belajar Mengajar. Jurnal Pendidikan Sejarah, 9(1), 1-14. https://doi.org/10.21009/JPS.091.01.

Silva, J. M., Godinho, T. M., Silva, D., \& Costa, C. (2019). A Community-Driven Validation Service for Standard Medical Imaging Objects. Computer Standars \& Interface, 61(1), 121-128. https://doi.org/10.1016/j.csi.2018.06.003.

Siwiendrayanti, A., Pawenang, E. T., \& Indarjo, S. (2019). Changes in knowledge, behavior, and environmental control for filariasis prevention with "Mandiri" pocket book in Pekalongan city society: A longitudinal study. Jurnal Pendidikan IPA Indonesia, 8(2), 177-184. https://doi.org/10.15294/jpii.v8i2.17766.

Smith, R. O., Scherer, M. J., Cooper, R., Bell, D., Hobbs, D. A., Pettersson, C., Seymour, N., Borg, J., Johnson, M. J., Lane, J. P., Sujatha, S., Rao, P. V. M., Obiedat, Q. M., MacLachlan, M., \& Bauer, S. (2018). Assistive technology products: a position paper from the first global research, innovation, and education on assistive technology (GREAT) summit. Disability and Rehabilitation: Assistive Technology, 13(5), 473-485. https://doi.org/10.1080/17483107.2018.1473895.

Snape, P., \& Zealand, N. (2017). Enduring Learning: Integrating C21st Soft Skills through Technology Education. Enduring Learning: Integrating C21st Soft Skills through Technology Education., 22(3), 4859.

Stover, K., Yearta, L., \& Harris, C. (2016). Experiential Learning for Preservice Teachers: Digital Book Clubs With Third Graders. Journal of Digital Learning in Teacher Education, 32(1), 5-12. https://doi.org/10.1080/21532974.2015.1055013.

Supriyadi, T., Julia, J., Aeni, A. N., \& Sumarna, E. (2020). Action research in hadith literacy: A reflection of hadith learning in the digital age. International Journal of Learning, Teaching and Educational Research, 19(5), 99-124. https://doi.org/10.26803/ijlter.19.5.6.

Suryani, S. D., Amin, M., \& Rohman, F. (2021). The influence of the research-based monograph book to improve pre-service teachers' knowledge, attitude, and behavior. Jurnal Pendidikan IPA Indonesia, 10(2), 292-302. https://doi.org/10.15294/jpii.v10i2.30180.

Suryaningsih, Y. (2017). Pembelajaran Berbasis Praktikum Sebagai Sarana Siswa Untuk Berlatih Menerapkan 
Keterampilan Proses Sains Dalam Materi Biologi. Jurnal Bio Education, 2(2), 49-57.

Suyatna, A., Maulina, H., Rakhmawati, I., \& Khasanah, R. A. N. (2018). Electronic versus printed book: A comparison study on the effectivity of senior high school physics book. Jurnal Pendidikan IPA Indonesia, 7(4), 391-398. https://doi.org/10.15294/jpii.v7i4.14437.

Tondeur, J., Scherer, R., Baran, E., Siddiq, F., Valtonen, T., \& Sointu, E. (2019). Teacher educators as gatekeepers: Preparing the next generation of teachers for technology integration in education. British Journal of Educational Technology, 50(3), 1189-1209. https://doi.org/10.1111/bjet.12748.

Uygarer, R., \& Uzunboylu, H. (2017). An investigation of the digital teaching book compared to traditional books in distance education of teacher education programs. Eurasia Journal of Mathematics, Science and Technology Education, 13(8), 5365-5377. https://doi.org/10.12973/eurasia.2017.00830a.

Weiss, D., Rydland, H. T., Øversveen, E., Jensen, M. R., Solhaug, S., \& Krokstad, S. (2018). Innovative technologies and social inequalities in health: A scoping review of the literature. PLoS ONE, 13(4), 120. https://doi.org/10.1371/journal.pone.0195447.

Winatha, K. R., Naswan, S., \& Ketut, A. (2018). Pengembangan E-modul Interaktif Berbasis Proyek Pada Mata Pelajaran Simulasi Digital Kelas X di SMK TI Bali Global Singaraja. Jurnal Teknologi Pembelajaran Indonesia, 8(1). https://doi.org/10.23887/jtpi.v8i1.2238.

Wusqo, I. U., Khusniati, M., Pamelasari, S. D., Laksono, A., \& Wulandari, D. (2021). The effectiveness of digital science scrapbook on students' science visual literacy. Jurnal Pendidikan IPA Indonesia, 10(1), 121-126. https://doi.org/10.15294/jpii.v10i1.27130.

YalÇintaŞ Sezgin, E., \& Ulus, L. (2017). The early literacy at preschool education: The book or the E-book? Turkish Online Journal of Educational Technology, 16(4), 77-83.

Yikici, B., Bastas, M., Altinay, F., Dagli, G., \& Altinay, Z. (2019). The Role of Technology For School Management and Development. Revista Inclusiones, 6(Special), 100-115.

Yildiz, U., \& Gunsoy, B. (2017). Macroeconomics Determinants of Sovereign Credit Ratings. International Journal of Business Social Science, 8(11), 118-125. https://doi.org/10.5539/ibr.v8n2p42.

Zaki, N. A. A., Zain, N. Z. M., Noor, N. A. Z. M., \& Hashim, H. (2020). Developing a conceptual model of learning analytics in serious games for stem education. Jurnal Pendidikan IPA Indonesia, 9(3), 330339. https://doi.org/10.15294/jpii.v9i3.24466.

Zetriuslita, Nofriyandi, \& Istikomah, E. (2020). The Increasing Self-Efficacy and Self-Regulated through GeoGebra Based Teaching reviewed from Initial Mathematical Ability (IMA) Level. International Journal of Instruction, 14(1), 587-598. https://doi.org/10.29333/IJI.2021.14135A. 